\title{
PROFESSIONAL TRAINING OF FUTURE MASTERS OF PRIMARY EDUCATION TO INNOVATIVE ACTIVITIES THROUGH THE PRISM OF A COMPETENCE APPROACH
}

\author{
OKSANA TSIUNIAK
}

\begin{abstract}
The current problems of the advanced system, which were most often used by masters who were studying for innovation, are updated. Theoretical analysis of scientific sources with understanding of the concept of "personal approach" is carried out. Changes of important aspects that are covered by methodological research in the field of work carried out in future Master's workplaces are analyzed. The essence and peculiarities of realization of the competence approach in the system of professional preparation of future masters of elementary education for innovative activity are considered. It is noted that the competence approach is aimed at the results of education not as a sum of learned information, but as the ability of a future specialist to creatively use the acquired knowledge in practice. It is concluded that the implementation of a competent approach in the system of training of future masters of elementary education in innovation ensures the achievement of a high level of quality professional training, the result of which is the competent personality of a future specialist, competitive in the labor market, able to act in an innovative educational environment.
\end{abstract}

Keywords: approach, education, competence approach, competence, professional competence, vocational training, future masters of elementary education, innovative activity.

"Education is the most powerful weapon, you can use to change the world."

Nelson Mandela

\section{INTRODUCTION}

Today, Ukrainian society needs professionals with innovative thinking and a keen desire to implement their ideas in social life, driven by information, economic, social, political, cultural and religious processes of the third millennium. The modern world requires young people to be able to respond efficiently and promptly to innovative changes that are taking place in society, to be selfsufficient, proactive, responsible citizens, successful people, that is, professionally competent. That is why the problem of effective professional training of future specialists is an urgent one, which will be able to easily adapt to the changing conditions of today and be competitive in the labor market.

Therefore, according to the Law of Ukraine "On Higher Education", the master's level of higher education corresponds the seventh qualification level of the National Qualifications Framework and 
envisages acquiring a person of advanced theoretical and / or practical knowledge, abilities, skills in the chosen specialty (or specialization), general principles of methodology / or professional activity, other competences sufficient to effectively accomplish tasks of an innovative nature of the appropriate level of professional activity" [6]. Master's degree programs involve training professionals with a high level of autonomy and responsibility in solving professional tasks. As experience shows, this requires not only sound knowledge of professional subjects, but also their effective application in practice and the ability to learn throughout life. Therefore, the task of implementing a competent approach in the system of professional preparation of future masters of elementary education for innovative activity, which involves the formation and development of professional and key competences of the individual, becomes urgent. At the same time, the idea of a competency-based approach is one of the answers to the question of what educational outcome is needed by the individual and is demanded by modern society.

\section{ANALYSIS AND DisCUSSION}

It is well known that the problem of training a competent person has been the subject of in-depth and in-depth research conducted by international organizations working in the field of education UNESCO, UNICEF, UNDP, the Council of Europe, Organization for European Cooperation, International Standards Department and others.

The formation of a new higher education system in Ukraine does not imply the imperfection of the previous one, but in the conditions when the demands and needs of the intellectual labor market are changing rapidly, the higher education system should allow students to receive not only theoretical professional training but also advanced and practical ones. It is important to train a competent specialist who has deep understanding and knowledge of his role in society, is able to creatively apply knowledge acquired in practice and able to work in a team following the ideas of partnership pedagogy.

The multifaceted preparation of the next generation of masters has become the leading task of higher education institutions today. I. Babin, V. Bondar, V. Osadchyi, O. Eremenko, S. Vitvitska, N. Batechko, P. Luzan, V. Lykova are engaged in researching the organization of professional and professional training of masters. Education was thoroughly considered in the writings of N. Bibik, V. Bidenko, O. Budnyk, V. Verbitsky, L. Vashchenko, E. Zeer, I. Zimnaya, O. Ovcharuk, O. Pometun, A. Khutorsky and others.

The analysis of scientific work on the identified problem allows to distinguish three stages of formation of the competence approach in education (competence education):

The first (1960-1970 biennium) - introduction in the scientific apparatus of the category "competence", creating prerequisites for the separation of concepts of competence.

Second (1970-1990) - use of the category of competence and competence in the theory and practice of language teaching, professionalism in management, management, teaching of communication, content of the concept "Skills / social skills" developed.

The third (since the 1990s) is characterized by the global integration of the approach to national education systems, reflected in the preparation of UNESCO documents, the implementation of this approach in the Bologna process.

Intelligence on this issue proves that the core competency approach to defining the essence of higher education is the pursuit of basic tasks: education should teach students the qualities necessary to achieve professional activity; the criteria and parameters for evaluating the results of modern education should be unified and expressed in terms and results that can be interpreted and taken into account in any country's educational institution. Quite rightly, in our opinion, N. Pobirchenko points out that a competent approach can be considered not only as a means of updating the content of education, but also as a mechanism for bringing it into line with the requirements of the present [9, p. 24-31]. 
It is worth mentioning that the formula of the New Ukrainian School offers nine key components, one of which is: "a new content of education based on the formation of competences needed for successful self-realization in society" [7].

The competence approach as a direction of modernization of education was substantiated by V. Lugovyi [8, p. 13-25], in the opinion of which competence content approach reflects the content of education, which is not reduced to a knowledge-oriented component, but involves the acquisition of a comprehensive experience in solving life problems, fulfillment of key functions, social roles, identification of competencies. The competency approach is not about the student's awareness, but the development of skills to solve problems that arise in life situations.

A. Yaroshenko, a scientist who considers the competence approach as "one of the directions of modernization of education and which implies high readiness of graduates of higher education institutions for successful activity in various spheres due to the formation of key competences systems in them and corresponds to the accepted in most development, is worthy of attention. Countries of the general concept of the educational standard and directly related to the transition in the design of the content of education and quality control systems to the system of key competences" [10, p. 5-12]. In the context of this problem, let us consider the importance of a competent approach in the system of professional training of future masters of elementary education for innovative activity in HSE.

The presence of the use of the concept "competent approach" in regulatory and conceptual documents, in the scientific reconnaissance of domestic and foreign educators shows that this approach becomes a reality of modern education and is actively implemented in the educational process of higher education institutions. It is a logical continuation of this statement by the views of Academician I. Bekh, who states: "a competent approach was an educational response to the pressing needs of modern society, especially the labor market" [1, p. 4].

We are fascinated by the opinion of the scientist O. Dubaseniuk, who states that "a competent approach reflects an integral manifestation of professionalism, which combines elements of professional and general culture (level of education sufficient for self-education and self-solving of cognitive problems), pedagogical experience and pedagogical activity to be specified in a certain system of knowledge, skills, readiness for professional activity" [5, p. 11]. Researcher S. Vytvytska examines the competence approach through a set of knowledge, abilities, skills, and ways of activity concerning certain processes and phenomena necessary to act qualitatively and productively [4, p. 168]. In other words, a competent approach orientates the education system not only to the accumulation of knowledge in the learning process, but also to the ability to use the acquired knowledge, to put them into professional activity.

It is logical that the focus is on the practical outcome, that is, on the ability of the undergraduates to act practically, using the acquired knowledge, skills and abilities, to carry out their own professional self-development and to take care of the readiness for innovative activity in different fields. For example, the formation of professional competence in higher education applicants can be done through project training. Project technologies have become widely used in higher education institutions: telecommunication projects, projects on the technology "Intelligence for the future", web-based quests. Project-based training promotes the development of self-knowledge skills, the use of innovative learning technologies, that they have acquired the subject knowledge already gained during their study at higher education institutions (HEI). It is advisable to create real pedagogical situations. We find the proper organization of independent work of undergraduates' particular important. It must be done in compliance with the following conditions: combination of classroom and extra-curricular independent work and methods of its implementation; creation of necessary educational and methodological support of independent work; systematic control over the results of independent work of undergraduates. In addition, we believe that effective implementation of a competent approach in vocational training involves introduction of the following conditions: updating training methods to promote; identifying and developing innovative competence; application of methods of training and education on a competent basis, which involves the formation and solution of practical problem situations using game methods; introduction of various forms of communication: conferences, lectures- 
discussions, lectures-consultations, application of alternative assessment systems of students' educational activity. At the same time, it is necessary to strengthen the professional orientation of training at the HEI through practical training; to increase the share of optional subjects in order to better acquaint students with the features of future activity; to increase hours for independent work and use of modern means of control over its conduct. After all, a significant growth in the independent work of undergraduates helps to increase their responsibility for their own performance. Innovative pedagogical and information technologies should also be used to help bring learning activities closer to future innovation activities. For the future, it is advisable to develop new vocational-oriented disciplines and their educational and methodological support, etc. In view of the above, we can say that a competent approach in the system of professional training of future masters of elementary education to innovative activity provides opportunities for future professionals: to analyze and systematize on a scientific basis the practical experience of pedagogical activity; to predict, plan expected results of activity and successfully manage pedagogical processes; optimize the use of resources to solve problems practically; create favorable conditions for personal development and self-development; to develop, introduce new technologies; to choose the most optimal technologies, a set of methods, techniques in order to succeed in their own innovative activity.

\section{CONCLUSIONS}

In general, it can be concluded that the improvement of the system of professional preparation of future Masters of primary education for innovation through the prism of a competent approach involves the formation of a motivated competent person, able:

- to navigate in an information space quickly, that is dynamically developing and constantly updated;

- to receive, use, create various information;

- to exercise autonomy in formulating tasks and solving them;

- to make informed decisions, to solve problems on the basis of the received knowledge, skills and skills, to take responsibility for the received result;

- to show activity and interest in learning the world;

- to realize the value of knowledge, science, creativity, education and self-education for life and activity;

- to be ready to learn throughout life, to apply the knowledge gained in practice.

The prospects for further scientific research are seen in the development of a structural and functional model of professional preparation of future masters of elementary education for innovation as a training system, which will clearly define the purpose, objectives and content of professional training of a competent specialist.

\section{REFERENCES}

[1] Beh I.D. Personal education. Lybid, Kyiv, 2008. (in Ukrainian)

[2] Budnyk O. Innovative Competence of a Teacher: best European Practices. Journal of Vasyl Stefanyk Precarpathian National University, 6 (1) (2019), 76-89. doi: 10.15330/jpnu.6.1.76-89.

[3] Budnyk O. Motivation of Students to the Professional Pedagogical Activities. Scientific Bulletin of Chetm. Section of Pedagogy, 1 (2018), 55-65. Available at: http://yadda.icm.edu.pl/yadda/element/bwmeta1. element.desklight-be55418b-854b-4b62-9d82-75a65bd087ac/

[4] Vytvytska S.S. Professional Teacher Education: Competent Approach. Vyd-vo ZhDU im. I. Franka, Zhytomyr, 2009. (in Ukrainian) 
[5] Dubaseniuk O.A. Professional Teacher Education: Competent Approach. Vyd-vo ZhDU im. I. Franka, Zhytomyr, 2011. (in Ukrainian)

[6] Law of Ukraine "On Higher Education". Available at: https://zakon.rada.gov.ua/laws/show/1556-18

[7] The New Ukrainian school concept. Available at: https://www.kmu.gov.ua/storage/app/media/reforms/ukrainska-shkola-compressed.pdf

[8] Luhovyi V.I. European concept of competence approach in higher education and problems of its implementation in Ukraine. Pedagogy and Psychology. Pedahohika i psykholohiia: naukovo-teoretychnyi ta informatsiinyi zhurnal, 2 (63) (2009), 13-25. (in Ukrainian)

[9] Pobirchenko N.S. Competitive approach in higher education institutions: theoretical aspect. Education and pedagogical science, 3 (2012), 24-31. (in Ukrainian)

[10] Yaroshenko A.O. Competency approach as one of the directions of improving the quality of education of social specialists training. Mizhnarodnyi naukovyi forum: sotsiolohiia, psykholohiia, pedahohika, menedzhment, 14 (2013), 5-12. Available at: http://nbuv.gov.ua/UJRN/Mnf_2013_14_3 (in Ukrainian)

Address: Oksana Tsiuniak, Vasyl Stefanyk Precarpathian National University, 57, Shevchenko Str., IvanoFrankivsk, 76018, Ukraine.

E-mail: oksana.tsiuniak@pnu.edu.ua

Received: 27.01.2019; revised: 02.03.2020.

Цюняк Оксана. Професійна підготовка майбутніх магістрів початкової освіти до інноваційної діяльності крізь призму компетентнісного підходу. Журнал Прикарпатського університету імені Василя Стефаника, 7 (1) (2020), 166-170.

У статті обгрунтовано актуальність проблеми удосконалення системи професійної підготовки майбутніх магістрів початкової освіти до інноваційної діяльності. Здійснено теоретичний аналіз наукових джеред з осмислення поняття "компетентнісний підхід". Проаналізовано змістові аспекти компетентнісного підходу як метододогічного орієнтиру у професійній підготовці майбутніх фахівців освітнього рівня “Магістр". Розглянуто сутність та особливості реалізації компетентнісного підходу у системі професійної підготовки майбутніх магістрів початкової освіти до інноваційної діяльності. Відзначено, що компетентнісний підхід спрямований на результати освіти не як суми засвоєної інформації, а як здатності майбутнього фахівця творчо використовувати набуті знання на практиці. Зроблено висновки, що реалізація компетентнісного підходу у системі професійної підготовки майбутніх магістрів початкової освіти до інноваційної діядьності забезпечуе досягнення високого рівня якісної фахової підготовки, результатом якої $е$ особистість майбутнього фахівця, конкурентоспроможного на ринку праці, здатного швидко орієнтуватися в інформаційному просторі, що динамічно розвивається й постійно оновлюеться; одержувати, використовувати, створювати різноманітну інформацію; виявляти самостійність у постановці завдань та їх вирішенні; приймати обгрунтовані рішення, вирішувати проблеми на основі отриманих знань, умінь і навичок, брати на себе відповідальність за отриманий результат; активно й зацікавлено пізнавати світ, усвідомлювати цінність знань, науки, творчості, освіти й самоосвіти для життя та інноваційної діяльності; навчатися протягом усього життя та працювати в інноваційному освітньому середовищі.

Ключові слова: підхід, освіта, компетентнісний підхід, компетентність, професійна компетентність, професійна підготовка, майбутні магістри початкової освіти, інноваційна діяльність. 